has shown that this can stimulate non-shivering thermogenesis in man. Cold-adapted subjects also showed an increased calorigenic action of noradrenaline (Joy, 1962 ; Davis, 1963), so that the slightly raised V.M.A. excretions found in this study may be important. Shivering tends to disappear in the cold-adapted subject, and this may explain why all except one of our patients with a relative hypothermia failed to shiver.

These observations emphasize certain aspects of the managements of these patients. Because of the reduced capacity to thermoregulate, with its attendant dangers of hypothermia or hyperthermia, body temperature must be accurately observed, using a low-temperature thermometer when indicated. Patients usually require more clothes and a warmer room than the average person, and the risk of hypothermia is obviously greatest during winter months and when they are treated at home, but even in hospital care is needed during treatment periods. If the patient develops a high body temperature steps should be taken to reduce it in order to avoid an excessive increase in the cardiac load. The aim should be to steer a course between the two extremes and keep body temperature close to normal. If the patient is seen to be shivering, complains of the cold, or has a subnormal temperature, the room temperature or his clothing should be promptly increased. The temperature at which he becomes comfortable and shivering ceases should be recorded and used as a guide to adjust his environment. Prompt treatment of the skin condition, usually with corticosteroids, is the best way of avoiding heart failure. The unexplained high mortality of patients with erythrodermic skin diseases may in large part be due to the haemodynamic and thermoregulatory problems we have discussed.

\section{Summary}

Haemodynamic studies on six patients with widespread erythrodermic skin conditions have shown marked increases in skin blood-flow equivalent to up to two-thirds of that seen in normal subjects when fully vasodilated by heat; there was a considerable further increase in skin blood-flow when the body temperature was raised. All had a raised venous pressure with hypervolaemia, and in two patients the cardiac output was moderately increased.

Body-temperature regulation was grossly disturbed. Four out of five patients had either a fever or an elevation of the set point for temperature regulation with body temperatures below the fever level. The capacity to thermoregulate is greatly diminished in these patients, and hypothermia, which is an important risk, is related to the high skin blood-flow and inability of the skin blood-vessels to constrict fully.

The basal metabolic rate was raised considerably in 9 out of 11 patients. Radioactive iodine studies showed no evidence of hyperthyroidism, but there was a slight increase in vanillyl mandelic acid excretion. The hypermetabolism is probably mainly due to the abnormal skin metabolism, but the development of non-shivering thermogenesis may also play a part.

Two of us (S. S. and J. M.) were supported by a grant from the Medical Research Council.

\section{REFERENCES}

Davis, T. R. A. (1963). Fed. Proc., 22, 777.

Fox, R. H., and Edholm, O. G. (1963). Brit. med. Bull., 19, 110. Goldsmith, R., Kidd, D. J., and Lewis, H. E. (1963). 'F. Physiol. (Lond.), 166, 548.

Fraser, R., Hobson, Q. J. G., Arnott, D. G., and Emery, E. W. (1953). Quart. F. Med., 22, 99.

Georges, R. J., and Whitby, L. G. (1964). F. clin. Path., 17, 64.

Hellon, R. F., and Clarke, R. S. J. (1959). Clin. Sci., 18, 1.

Joy, J. T. (1962). Physiologist, 5, 164.

Krook, G. (1960). Acta derm.-venereol. (Stockh.), 40, 142

Magnusson, B. (1960). Ibid., 40, 161.

Pisano, J. J., Crout, J. R., and Abraham, D. (1962). Clin. chim. Acta, Robertson,

Robinson, S. (1949). In Physiology of Heat Regulation and Science of Clothing, edited by L. H. Newburgh, p. 206. Saunders, London.

Sharpey-Schafer, E. P. (1955). Brit. med. f., 1, 693.

Sharpey-Schafer, E. P. (1955). Brit.
Shuster, S. (1963). Lancet, 1, 1338.

Shuster, S. (1963). Lancet, 1, 1338.

Tay and Wilkinson, P. (1963). Brit. F. Derm., 75, 344.

Taylor, S. H., and Shillingford, J. P. (1959). Brit. Heart f., 21, 497.

Wade, O. L., and Bishop, J. M. (1962). In Cardiac Output and Regional Blood Flow, p. 34. Blackwell, Oxford.

\title{
Acute Infections of the Urinary Tract and the Urethral Syndrome in General Practice
}

\author{
D. J. A. GALLAGHER,* M.B., M.MED.SC. ; J. Z. MONTGOMERIE, † M.B., M.R.A.C.P. ; \\ J. D. K. NORTH, $†$ M.B., D.PHIL., M.R.C.P., F.R.A.C.P.
}

Brit. med. F., 1965, 1, 622-626

What is the significance of single or repeated attacks. of infection of the urinary tract? Our knowledge of these infections comes mainly from studies of patients in hospitals (Wharton et al., 1937 ; Jackson et al., 1957 ; Winberg and Barr, 1960) and from post-mortem studies (Weiss and Parker, 1939; MacDonald et al., 1957). In contrast, most infections of the urinary tract are diagnosed and treated at home by the general practitioner. It is therefore important to examine the natural history of these infections. We report a prospective study planned to investigate the type of infection occurring in general practice, the response to treatment with sulphafurazole (Gantrisin), and the incidence of recurrent infections.

Urologists often see patients who complain of frequency and dysuria without evidence of infection in the urine. The aetio-

* Auckland Faculty, College of General Practitioners.

+ Medical Unit, Auckland Hospital, Auckland, New Zealand. logy of this urethral syndrome is obscure and has been attributed to an anxiety neurosis (Gray and Pingelton, 1956; Zufall, 1963). In this study we found that the urethral syndrume was common in general practice; many patients presenting with symptoms of infection had sterile urine. To assess the urethral syndrome these patients have been compared with the remaining patients with definite infection in the urine seen in the survey.

\section{Methods}

In New Zealand patients with acute infections in the urinary tract are often treated with a sulphonamide by general practitioners who do not have facilities for bacteriological examination of the urine. This study was designed to determine the deficiencies of treating patients in this way. 
Eight doctors ${ }^{1}$ who had typical urban general practices took part in the survey, which extended over eight months and was designed to include all patients diagnosed on symptoms as having acute infections of the urinary tract. Patients known to have such infections were not included unless they developed further symptoms during the trial.

The practitioner, on seeing the patient, recorded the symptoms and physical signs. A qualified nurse from Auckland Hospital then visited the patient's home. For women, the nurse prepared the vulva with chlorhexidine solution, and then collected a catheter specimen of urine. Disposable plastic catheters in sterile containers were used to reduce to a minimum the risk of introducing infection. The urine specimen was collected direct into a wide-mouthed sterile jar which was immediately placed in a vacuum-flask packed with ice to reduce bacterial growth. The initial specimen of urine from each female patient was collected by catheter because many of these patients required prompt treatment. Adequate collection of mid-stream specimens by a strange nurse would have been difficult in the patient's home, and without the opportunity of repeating some of the specimens the results would have been difficult to interpret. Mid-stream specimens were obtained from the male patients after cleansing the glans penis with chlorhexidine solution.

Catheter and mid-stream urines were examined in the laboratory within one hour of collection for quantitative bacterial count, protein, deposit, and culture. Catheter specimens of urine were regarded as infected if there were more than 10,000 bacteria per $\mathrm{ml}$. of urine (Effersøe and Jensen, 1963).

All patients were treated with sulphafurazole, $1 \mathrm{~g}$. four times daily for 10 days, unless there was a contraindication to using this drug. This treatment reduced further the chance of bacteria introduced by the catheter causing an infection in the urine.

Two weeks after the initial infection a mid-stream specimen of urine was collected at the hospital. Further mid-stream specimens of urine were collected at six weeks and at three months, when the patients were seen at the hospital by one doctor. The following investigations were then carried out: haemoglobin, erythrocyte sedimentation rate (Westergren), blood urea (measured by the AutoAnalyzer), creatinineclearance (Edwards and Whyte, 1958), 24-hour urinary protein, and intravenous pyelogram. If indicated, cystoscopy or reflux cystograms were carried out.

\section{Results}

During eight months 135 patients were seen with symptoms of an acute infection in the urinary tract. A specimen of urine

TABLB I.-Quantitative Bacterial Counts of Urine

\begin{tabular}{|c|c|c|c|}
\hline \multirow{2}{*}{\multicolumn{2}{|c|}{ Bacterial Count (per ml.) }} & \multicolumn{2}{|c|}{ No. of Patients } \\
\hline & & \multirow{2}{*}{$\begin{array}{c}\text { With Infection } \\
56 \\
\frac{8}{13}\end{array}$} & \multirow{2}{*}{ 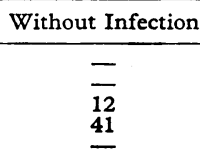 } \\
\hline $\begin{array}{l}\text { More than } 100,000 \\
10,000-100,000 \\
\text { Less than } 10,000 \quad \ldots\end{array}$ & $\begin{array}{l}\ldots \\
\cdots \\
\cdots\end{array}$ & & \\
\hline Total & .. & 77 & $53^{\prime}$ \\
\hline
\end{tabular}

* Urines examined outside normal laboratory hours.

was obtained from 130 patients, and the results from these patients are reported below. Only $77(59 \%)$ of the 130 patients were found to have infected urine. These 77 patients are compared with the other 53 patients without infected urines.

${ }^{3}$ Dr. D. G. Campbell, Dr. D. J. A. Gallagher, Dr. J. W. G. Gibb, Dr. M. M. Harding, Dr. J. B. Lovell-Smith, Dr. M. Pearl, Dr. C. N. College of General Practitioners.
Quantitative bacterial counts of all patients are given in Table I. Quantitative counts were not done in 13 patients from whom the urine was collected after normal laboratory hours. Only 8 of the 77 infected patients had bacterial counts between 10,000 and $100,000 / \mathrm{ml}$. In 41 of the 53 patients without infection the bacterial count was zero.

\section{Patients With Infected Urine}

Age and Sex.-Of the 77 patients with infection 71 werc females and 6 males-a male-to-female ratio of $1: 12$. Seven patients (five girls and two boys) were under 12 years of age.

Marriage and Pregnancy.-The marital status of the 35 women aged 16 to 40 with infected urine is shown in Table II. Fourteen of these were either unmarried or nulliparous. Of the remaining 21 , who were either pregnant or multiparous, 8 gave a history of infection before their first pregnancy. The majority ( 22 out of 35 ) of these patients therefore had infection in the urine before their first pregnancy.

TABLE II.-Relation of Infection to Marriage and Pregnancy in Women

\begin{tabular}{|c|c|c|c|c|c|c|}
\hline & & & \multicolumn{2}{|c|}{$\begin{array}{c}\text { Patients } \\
\text { With Infection }\end{array}$} & \multicolumn{2}{|c|}{$\begin{array}{c}\text { Patients } \\
\text { Without Infection }\end{array}$} \\
\hline & & & No. & $\%$ & No. & $\%$ \\
\hline $\begin{array}{l}\text { Unmarried } \\
\text { Married \{ } \\
\text { Pregnant }\end{array}$ & $\begin{array}{ll} & \\
\text { Nulliparous } & \ldots \\
\text { Multiparous } & \ldots \\
& . .\end{array}$ & $\begin{array}{l}\cdots \\
\cdots\end{array}$ & $\begin{array}{r}8 \\
6 \\
14 \\
7\end{array}$ & $\begin{array}{l}23 \\
17 \\
40 \\
20\end{array}$ & $\begin{array}{l}7 \\
5 \\
8 \\
8\end{array}$ & $\begin{array}{l}25 \\
18 \\
28 \cdot 5 \\
28 \cdot 5\end{array}$ \\
\hline Tota & $\ldots$ & $\ldots$ & 35 & 100 & 28 & 100 \\
\hline
\end{tabular}

Abnormalities of Urinary Tract.-Obstruction or urinary retention was an infrequent cause of infection and could have been a contributory factor in only nine patients. One man was infected after prostatectomy. A gross cystocele with dilatation of the upper urinary tract was seen in one patient; smaller cystoceles were found in four other patients. In three patients the intravenous pyelogram showed unilateral pelviureteric narrowing with some obstruction. Two other patients had small renal calculi without obstruction.

Reflux cystograms were carried out in four children who had persistent or recurrent infections. One child showed vesico-ureteric reflux; another had small diverticuli of the bladder close to the lower ends of the ureters without vesicoureteric reflux.

Bacteria Causing Initial Infections.-Bacteria isolated from the urine of these patients are shown in Table III. Escherichia coli, which caused the infection in $60 \%$ of our patients, was the predominant organism here as in most groups of patients with urinary infections. The isolation of coagulase-negative staphylococci in the urine of 12 patients was unexpected. In normal subjects coagulase-negative staphylococci can be isolated from the urethra in small numbers and may occur as a contaminant in urine (Guze and Beeson, 1956). The other findings in the urine of these 12 patients suggest that these organisms were causing definite infections. Bacterial counts greater than 100,000 organisms per ml. were found in 11 urines, significant pyuria (more than five white cells per high-power field)

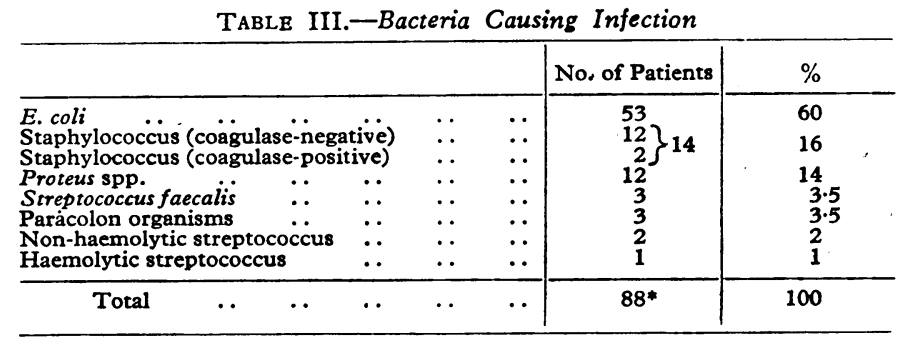

* 11 patients had mixed infections. 
occurred in 10 urines, and proteinuria was found in seven urines. Only 2 of these 12 patients had mixed urinary infections.

Response to Treatment.-A good response to sulphafurazole occurred in $57(79 \%)$ of 72 patients; the drug was contraindicated in the remaining patients. Of the 16 patients whose urine did not clear with sulphafurazole, the infecting organism was E. coli in nine; Proteus in six ; and Str. faecalis in one. In vitro testing with disks indicated that 9 of the 16 organisms were apparently sensitive to sulphafurazole.

Persisting or Recurrent Infections. - The rate of recurrence after treatment was high. Table IV gives details of 69 patients with infections in whom follow-up was complete. Sixteen patients had persisting infections after treatment and nine others had recurrent infections within three months-a total of 25 of the 69 patients with initial infection of the urine.

TABLE IV.-Persistent or Recurrent Infections in the Urinary Tract

\begin{tabular}{c|c|c|c|c|c|c}
\hline \multirow{2}{*}{ Bacteriuria } & \multicolumn{3}{|c|}{ Patients with Initial Infection } & \multicolumn{1}{c|}{$\begin{array}{c}\text { Patients Without } \\
\text { Initial Infection } \\
\text { (46 Cases) }\end{array}$} \\
\cline { 2 - 7 } & $\begin{array}{c}\text { Infection } \\
\text { Persisted }\end{array}$ & $\begin{array}{c}\text { Infection } \\
\text { Recurred }\end{array}$ & Total & $\%$ & $\begin{array}{c}\text { Infection } \\
\text { Occurred }\end{array}$ & $\%$ \\
\hline $\begin{array}{l}\text { With symptoms } \\
\text { Without symptoms.. }\end{array}$ & 8 & 6 & 14 & 20 & 4 & 9 \\
\hline Total ... & 8 & 3 & 11 & 16 & 9 & 19 \\
\hline
\end{tabular}

Asymptomatic Bacteriuria.-Eleven patients had persisting or recurrent infections without symptoms. In five of these the urine cleared spontaneously without further treatment. One other patient developed symptoms, so that the prolonged asymptomatic bacteriuria occurred in five patients.

Renal Function.-Renal damage, judged by impaired tests of renal function or changes in the intravenous pyelogram, was seen in very few patients. The blood urea was normal in all patients, and a creatinine clearance of less than $80 \mathrm{ml}$. a minute was observed in only three patients. Definite changes of pyelonephritis (Hodson, 1959) were present in the intravenous pyelogram in five patients. Lesser changes in the calices (Brod, 1956 ; Relman, 1960) and renal narrowing of the renal cortex in the absence of caliceal distortion may or may not signify renal damage from infection. Four patients had cortical narrowing without caliceal changes and four patients had caliceal changes without extrinsic abdominal pressure. Thirteen of the patients therefore had changes in the pyelogram suspicious or diagnostic of pyelonephritis.

\section{Patients Without Infected Urine}

The results of these patients have been compared with those with infected urine. The interesting finding was the many

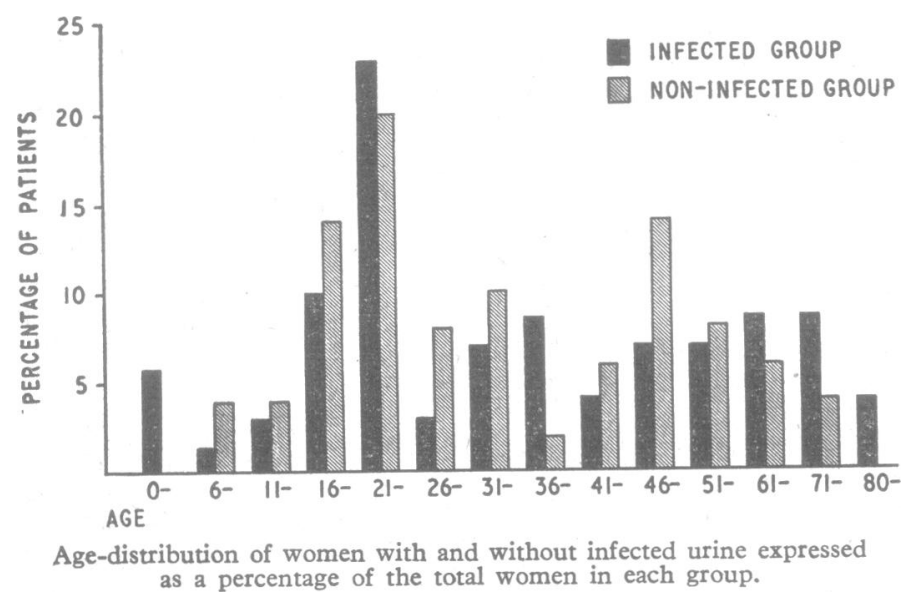

similarities rather than the differences between the two groups of patients.

Initial Urine.-Minor abnormalities were found in the urine in only 9 of the 53 patients without infection. A trace of proteinuria occurred in eight patients and more than 5 white cells per high-power field were found in the urine of seven.

Age and Sex.-The age incidence in the uninfected patients was similar to that of those with infection, although there were slightly more female patients aged 40 to 50 without infection (see Chart). There were only three men whose urine was without infection; two of these had frequency and nocturia due to prostatic hypertrophy.

Marriage and Pregnancy.-There were 63 female patients in the survey aged 16 to 40 years, of whom $43 \%$ without infection and $40 \%$ with infection were either unmarried or nulliparous (Table II). The only difference between the two groups was a higher incidence of pregnancy in patients without infection $(28.5 \%$ compared with $20 \%)$. This was not statistically significant.

Past History of Symptoms Related to the Urinary Tract.These symptoms were more common in patients without infection $(79 \%$, compared with $62 \%$ of patients with infected urines) (Table V). For these previous episodes treatment had been given to rather more than half the patients from both the infected and the uninfected groups. There were no differences in the pattern of previous episodes in the two groups of patients or in the time from the onset of the first attack.

TABLE V.-Previous History of Infections of the Urinary Tract

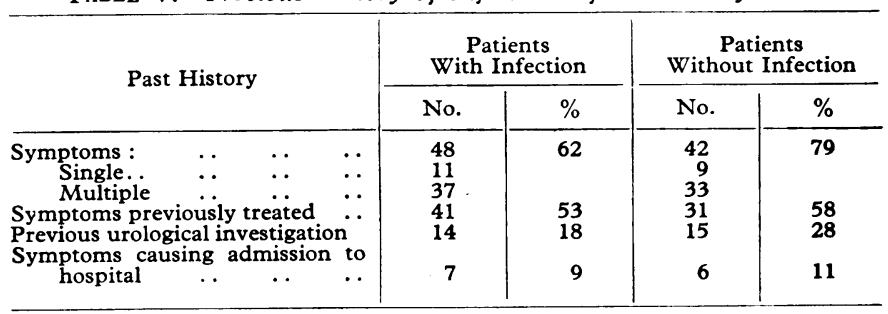

Symptoms.-These were recorded by the general practitioner before the results of the urine were known, and showed only minor differences between the infected and uninfected patients (Table VI) ; fever, a history of haematuria, and dysuria were significantly more common in patients with infection. Assessment of symptoms is subjective and difficult. The degree of certainty with which the diagnosis was made before bacteriological examination of the urine is given in Table VII. Among the uninfected patients there were fewer cases in which the diagnosis appeared certain (19\%) than among the infected

\begin{tabular}{|c|c|c|c|c|c|c|}
\hline \multicolumn{3}{|l|}{ Symptom } & \multicolumn{2}{|c|}{$\begin{array}{c}\begin{array}{c}\text { Patients } \\
\text { With Infection } \\
(77)\end{array} \\
\end{array}$} & \multicolumn{2}{|c|}{$\begin{array}{c}\text { Patients } \\
\text { Without Infection } \\
\text { (53) }\end{array}$} \\
\hline & & & No. & $\%$ & No. & $\%$ \\
\hline $\begin{array}{ll}\text { Fever } & . . \\
\text { Dysuria . . } & \ldots \\
\text { Haematuria } & \ldots \\
\text { Frequency } & \ldots \\
\text { Loin pain .. } & \text {. . } \\
\text { Lower abdominal pain }\end{array}$ & $\begin{array}{l}\ldots \\
\ldots \\
\cdots \\
\cdots\end{array}$ & $\begin{array}{l}\ldots \\
\cdots \\
\cdots \\
\cdots\end{array}$ & $\begin{array}{l}28 \\
71 \\
18 \\
70 \\
26 \\
49\end{array}$ & $\begin{array}{l}36 \\
92 \\
23 \\
91 \\
34 \\
64\end{array}$ & $\begin{array}{r}8 \\
38 \\
7 \\
50 \\
17 \\
34\end{array}$ & $\begin{array}{l}15 \\
72 \\
13 \\
94 \\
32 \\
64\end{array}$ \\
\hline
\end{tabular}

TABLE VII.-Clinical Assessment of Diagnosis of Infection of the

\begin{tabular}{|c|c|c|c|c|c|c|c|}
\hline \multirow{2}{*}{\multicolumn{4}{|c|}{ Clinical Assessment }} & \multicolumn{2}{|c|}{$\begin{array}{c}\text { Patients } \\
\text { With Infection }\end{array}$} & \multicolumn{2}{|c|}{$\begin{array}{c}\text { Patients } \\
\text { Without Infection }\end{array}$} \\
\hline & & & & \multirow{2}{*}{$\begin{array}{r}\text { No. } \\
27 \\
34 \\
13 \\
3\end{array}$} & \multirow{2}{*}{$\begin{array}{r}\% \\
35 \\
44 \\
17 \\
4\end{array}$} & No. & $\%$ \\
\hline $\begin{array}{l}\text { Certain } \\
\text { Highly probable } \\
\text { Probable .. } \\
\text { Doubtful .. }\end{array}$ & $\begin{array}{l}\cdots \\
\cdots \\
\cdots\end{array}$ & $\begin{array}{l}\cdots \\
\cdots \\
\cdots \\
\end{array}$ & $\begin{array}{l}\cdots \\
\cdots \\
\cdots\end{array}$ & & & $\begin{array}{r}10 \\
22 \\
12 \\
9\end{array}$ & $\begin{array}{l}19 \\
41 \\
23 \\
17 \\
\end{array}$ \\
\hline Total .. & 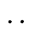 & $\cdots$ & - & 77 & 100 & 53 & 100 \\
\hline
\end{tabular}


patients $(35 \%)$. Nevertheless, on the history, an infection of the urinary tract was the probable diagnosis in the great majority of patients with sterile urine.

Recurrent Infections.-Of 46 patients without initial infection $13(28 \%)$ developed bacteriuria within three months (see Table IV). This is slightly less than the incidence of persistent or recurrent infection in the other group. In 9 of the 13 patients bacteriuria was asymptomatic and cleared without treatment in six, persisting in the remaining three.

Renal Function.-The blood urea was raised in one uninfected patient, and five of these patients had a creatinine clearance less than $80 \mathrm{ml}$. a minute, compared with three patients with initial infection. One patient without infection showed definite changes of pyelonephritis on the intravenous pyelogram. Minor caliceal changes without narrowing of the renal cortex were seen in two other uninfected patients. Duplex ureters occurred in three patients from each group, and a horseshoe kidney in one patient without infection.

\section{Discussion}

We are aware of only two other studies of infection of the urinary tract in general practice (Fry et al., 1962 ; Loudon and Greenhalgh, 1962). This may be due to difficulties in obtaining adequate specimens of urine for culture from all patients in general practice. In the course of this survey we found many difficulties in obtaining adequate co-operation from some of the patients who originally went to their own doctor for personal treatment. Of the 135 patients who consulted their doctors we obtained a satisfactory specimen of urine for examination in the laboratory in $130(96 \%)$ and a complete follow-up in $115(85 \%)$.

The study was designed to follow present methods of practice in New Zealand and to observe with bacteriological studies the effectiveness or deficiencies of the regime used. We did not expect to find the large number of patients presenting to their doctors with symptoms strongly suggestive of an acute infection in the urinary tract who did not have evidence of infection when the urine was cultured. Had we attempted this study using only mid-stream collections of urine when there was no opportunity of repeating the examination before treatment in most patients, we would have missed some of the sterile urines and had many more doubtful infections of the urinary tract. Apart from special surveys, mid-stream collection of urine is, we strongly believe, the correct method to use in practice when treating patients with urinary infections.

It is widely held that urinary infections in women occur either during pregnancy with dilatation of the upper urinary tract or immediately after pregnancy because of trauma to the genital tract during labour. Infections of the urinary tract in married women without children were commonly seen by Loudon and Greenhalgh (1962). We also observed a high incidence of these infections in married women before their first pregnancy. The increased incidence of infection in married women is probably the result of sexual activity with marriage.

The organisms responsible for infections of the urinary tract in general conform to the pattern observed by Loudon and Greenhalgh (1962). The one difference was the number of infections apparently due to coagulase-negative staphylococci (12 out of 88 infected urines). These organisms are commonly regarded as occurring in mixed culture, often with urological abnormalities, or after surgery to the genito-urinary tract. It was surprising to find a large number of uncomplicated infections caused by this organism in these patients. Unfortunately the nomenclature of this group is not uniform, and organisms reported as micrococci (Loudon and Greenhalgh, 1962) or Gram-positive cocci by others may include coagulase-negative staphylococci. Kunin et al. (1964) observed staphylococci.in up to $16 \%$ of girls with recurrent infections of the urine. This organism is often regarded as a contaminant (Kass, 1960 ; Kleeman et al., 1960). Disposable catheters and catheter specimens of urine were used in our study to avoid contamination. The urine was cooled in a container packed with ice to reduce bacterial growth after collection, and quantitative bacterial counts were made within one hour. The growth of these organisms in such large numbers associated with pyuria and proteinuria in our study suggests infection rather than contamination of the urine.

Mixed infections are commonly thought to occur only in patients seen in hospital with obstruction in the lower urinary tract or after instruments have been passed per urethram. Mixed infections, however, were not exceptional in our study, occurring in 11 out of 77 patients. Loudon and Greenhalgh (1962) similarly found mixed infections in 14 out of 143 patients in general practice.

Sulphafurazole was effective, as judged by the urine three days after stopping treatment, in four out of every five patients treated. In vitro sensitivity predicted the failure in only seven of the remaining 16 patients.

Infections persisting or recurring after treatment usually caused symptoms. Of 115 patients seen in this study with adequate follow-up only six had persistent asymptomatic bacteriuria during the next three months. The period of followup is short and other patients may well develop persistent asymptomatic bacteriuria after this time. The importance of asymptomatic bacteriuria is not known. Of 11 patients with asymptomatic bacteriuria, in five the urine spontaneously cleared of bacteria. Kass (1960) suggested that asymptomatic bacteriuria plays a key part in the pathogenesis of pyelonephritis and that these patients frequently develop overt symptoms.

The term "urethral syndrome," and synonyms, including cystalgia, urethrotrigonitis, and non-specific urethritis, indicate our poor understanding of the condition. Suggested aetiological factors include allergy (Kindall and Nickels, 1949), nonspecific infection (Folsom, 1931 ; Eberhart, 1958), congestion of the urethra (Ormond, 1935), senile atrophy of periurethral glands (Youngblood et al., 1957), obstruction (Davis, 1956), and anxiety neurosis (Gray and Pingelton, 1956 ; Zufall, 1963). Winsbury-White (1960) concluded that chronically infected urethral glands were responsible for recurrent symptoms. Bennett-Jones (1962) thought this was unlikely in the absence of organisms in the urine.

In comparing patients with and without infections in the urine we observed several factors which led us to believe that many cases of "urethral syndrome" are probably due to infection confined to the urethra and surrounding glands. Most patients in both groups had received treatment for symptoms of infection of the urinary tract in the past. In both groups women predominated and the age-distribution was similar, with a peak incidence in the 21-25 age-group. Presenting symptoms, although more definite in patients with urine infection, were similar in both groups. Bacteriuria developed during the short period of observation in 13 out of 46 patients without initial infection. Freedman (1960) reported cases with proved chronic pyelonephritis which were observed to develop further symptoms without bacteriuria. Our group of patients with the urethral syndrome did not include intractable cases with gross granulomatous changes, polypi, and urethral strictures, as are often reported from urological clinics.

We do not have direct evidence to show that infection is the major factor responsible for the urethral syndrome. Catheter specimens of urine precluded collecting the initial specimen of urine which passed through the urethra. Urethral swabs would have been of some, but limited, value. The method of collection of these swabs is critical. Unless collected by a doctor with the patient on a suitable table, the bacteria found would in many cases be only part of the normal flora from the vulva around the urethral orifice. 
Summary

An unselected group of 130 patients with symptoms of an acute infection of the urinary tract have been studied from general practice. Only $77(59 \%)$ of these 130 patients had infected urine. Treatment with sulphafurazole was possible in 72 , and was effective in 57 (79\% of those treated). A high incidence of infection observed in young women was apparently related to sexual activity rather than child-bearing.

Of the patients with symptoms suggesting acute infections of the urine $41 \%$ had urine free of infection on culture. These patients were regarded as having the "urethral syndrome."

Adequate follow-up was possible in 115 (85\%) patients; infection persisted or recurred in the three months after treatment in 25 out of 69 patients with initial infection. Bacilluria developed in the same period in 13 out of 46 patients without initial infection. Similarities between the patients with and without definite infection in the initial urine suggest that the "urethral syndrome" represents infection confined to the urethra and adjoining glands. This syndrome is part of the spectrum of infections of the lower urinary tract.

We are grateful to Sister E. C. Budge, of the District Nursing Service of the Auckland Hospital Board, for seeing patients in this study, and to Mr. J. Holland, who, with technicians of the Central Laboratory of the Auckland Hospital, examined the urines. We would thank Miss T. Hewitt for secretarial work involved in the trial. Roche Products Ltd. generously gave a grant-in-aid and supplied sulphafurazole (Gantrisin). Dr. J. Z. Montgomerie was supported by a grant from the New Zealand Medical Research Council.
REFERENCES

Bennett-Jones, M. J. (1962). Lancet, 1, 299.

Brod, J. (1956). Ibid., 1, 973.

Davis, D. M. (1956). 7. Urol. (Baltimore), 76, 270.

Eberhart, C. (1958). Ibid., 79, 293.

Edwards, K. D. G., and Whyte, H. M. (1958). Aust. F. exp. Biol. med. Sci., 36, 383.

Effersøe, P., and Jensen, E. (1963). Lancet, 1, 1342.

Folsom, A. I. (1931). F. Amer. med. Ass., 97, 1345.

Freedman, L. R. (1960). In The Biology of Pyelonephritis edited by E. L. Quinn and E. H. Kass, p. 345. Churchill, London.

Fry, J., Dillane, J. B., Joiner, C. L., and Williams, J. D. (1962). Lancet, 1, 1318.

Gray, L. A., and Pingelton, W. B. (1956). f. Amer. med. Ass., 162, 1361.

Guze, L. B., and Beeson, P. B. (1956). New Engl. F. Med., 255, 474.

Hodson, C. J. (1959). Proc. roy. Soc. Med., 52, 669.

Jackson, G. G., Poirier, K. P., and Grieble, H. G. (1957). Ann. intern. Med., 47, 1165.

Kass, E. H. (1960). In The Biology of Pyelonephritis, edited by E. L. Quinn and E. H. Kass, p. 399. Churchill, London.

Kindall, L., and Nickels, T. T. (1949). F. Urol. (Baltimore), 61, 222.

Kleeman, C. R., Hewitt, W. L., and Guze, L. B. (1960). Medicine (Baltimore), 39, 3.

Kunin, C. M., Deutscher, R., and Paquin, A. (1964). Ibid., 43, 91.

Loudon, I. S. L., and Greenhalgh, G. P. (1962). Lancet, 2, 1246.

MacDonald, R. A., Levitin, H., Mallory, G. K., and Kass, E. H. (1957). New Engl. 7. Med., 256, 915.

Ormond, J. K. (1935). F. Urol. (Baltimore), 33, 483.

Relman, A. S. (1960). In The Biology of Pyelonephritis, edited by E. L. Quinn and E. H. Kass, p. 355. Churchill, London.

Weiss, S., and Parker, F., jun. (1939). Medicine (Baltimore), 18, 221.

Wharton, L. R., Gray, L. A., and Guild, H. G. (1937). 9. Amer. med. Ass., 109, 1597.

Winberg, J., and Barr, M. (1960). Acta paediat. (Uppsala), 49, 203.

Winsbury-White, H. P. (1960). Proc. roy. Soc. Med., 53, 1016.

Youngblood, V. H., Tomlin, E. M., and Davis, J. B. (1957). ₹. Urol. (Baltimore), 78, 150.

Zufall, R. (1963). F. Amer. med. Ass., 184, 894.

\title{
Source of Elevated Serum Enzyme Activities in Patients with Megaloblastic Erythropoiesis Secondary to Folic-acid Deficiency
}

\author{
B. A. ElliOTT,* M.D., M.C.PATH. ; A. F. FLEMING, $†$ M.B., B.CHIR.
}

Brit. med. F., 1965, 1, 626-628

Elevated serum lactate dehydrogenase and $\alpha$-hydroxybutyrate dehydrogenase activities in patients with anaemia of pregnancy have been reported by Fleming and Elliott (1964). These high activities were not related to the severity of the anaemia but to the degree of megaloblastic marrow changes, and they fell rapidly with folic-acid therapy before the packed cell volume (P.C.V.) values rose, and before the restoration of wholly normoblastic erythropoiesis. A similar sequence of events has been observed in the levels of serum lactate dehydrogenase (Amelung, 1960) and of serum $\alpha$-hydroxybutyrate dehydrogenase (Elliott and Wilkinson, 1963) in patients on treatment for pernicious anaemia.

These observations suggest the megaloblastic tissues as the source of the elevated serum enzyme levels. In patients with pernicious anaemia the megaloblasts have been reported to be rich in enzymes (Heller et al., 1959), and it has been postulated that these are released into the blood by the increased destruction within the marrow of the abnormal red-cell precursors (Heller et al., 1960a). A similar process might explain the high serum lactate dehydrogenase and $\alpha$-hydroxybutyrate dehydrogenase activities in patients with folic-acid deficiency.

\footnotetext{
* Senior Lecturer, Department of Chemical Pathology, University College

Hospital, Ibadan, Nigeria.
† Senior Registrar, Subdepartment of Haematology, University College Hospital, Ibadan, Nigeria.
}

Since these patients are commonly admitted to University College Hospital, Ibadan, it was decided to investigate the relation between their blood serum and bone-marrow lactate dehydrogenase and $\alpha$-hydroxybutyrate dehydrogenase activities.

\section{Materials and Methods}

Patients Studied.-Six patients with Burkitt's tumour were found to have normoblastic marrows when they were investigated prior to chemotherapy. Of 17 patients with anaemia (see Table) the marrows of three showed early transitional megaloblastic change, four showed transitional change, and 10 were frankly megaloblastic. Fourteen of these patients were pregnant, and three had been recently delivered.

Serum Folic-acid Activities.-Activities were measured by bioassay using Lactobacillus casei as the test organism (Herbert, 1961).

Serum Vitamin-B $B_{12}$ Activities.-These were assayed using L. leichmannii as the test organism (Rosenthal and Sarett, 1952).

Marrow Preparations.-Marrow specimens were collected from the iliac crest using ethylenediamine-tetra-acetic acid as an anticoagulant. Heparin and oxalate were not used, as they partially inhibit enzyme activity (Plummer and Wilkinson, 